\title{
The Annual Reproductive Cycle of Silurus microdorsalis, a Korean Endemic Species
}

\author{
Se-Un Ki' ${ }^{1}$ and ${ }^{\dagger}$ Won-Kyo Lee ${ }^{2}$ \\ ${ }^{1}$ Freshwater Fish Research Institute, Jangsung 57211, Korea \\ ${ }^{2}$ Dept. of Aqualife Science, Chonnam National University, Yeosu 59626, Korea
}

\begin{abstract}
The annual reproductive cycle of the Korean endemic slender catfish, Silurus microdorsalis, was examined histologically regarding water temperature and day length of habitat, gonadosomatic index (GSI), and development characteristics of female and male gonads. The maximum GSI value was found in May, $1.23 \pm 0.33$ and $11.77 \pm 3.23$ for male and female respectively (habitat water temperature $21.5^{\circ} \mathrm{C} / 13.59 \mathrm{hr}$ day length). On the other hand, the minimal level was $0.63 \pm 0.10 \mathrm{in} \mathrm{Ju}-$ ly $\left(26.5^{\circ} \mathrm{C} / 14.17\right)$ for male and $1.36 \pm 0.08$ in October $\left(20^{\circ} \mathrm{C} / 11.2 \mathrm{hr}\right)$ for female. We compared and calculated the stages of testis and ovary development process in order to determine the germ cell development characteristics and the reproductive cycle. According to results, we classified the annual reproductive cycle of the slender catfish into five stages: Growing phase (December-February), Mature phase (March-April), Ripe and spawning phase / Releasing phase in male (May-June), Degenerative phase (July-August), and Resting phase (September-November).
\end{abstract}

Key words : Korean endemic fish, Catfish, Silurus microdorsalis, Gonadosomatic index(GSI), Reproductive cycle

\section{INTRODUCTION}

The far eastern catfish, Silurus asotus and the slender catfish, Silurus microdorsalis belonging to the Siluridae are only two species that inhabit in Korea (Mori, 1936; Jeon, 1984). S. asotus prefer to dwell in the muddy floor of rivers and lakes and distributed in Korea, Japan, Taiwan, and China. On the other hand, S. microdorsalis is an endemic species in Korea which is found in only mountainous streams (Park \& Kim, 2005).

$S$. asotus is one of the most important fresh water aquaculture species in Korea. It produces 4,764 tons in 2014, 4,267 tons in 2015, and 4,953 tons in 2016 (National Sta- tistics Office Database). S. microdorsalis has attracted a lot of attention as a promising species, but until now only a small number of seedlings has produced at the regional research institute.

The released young fish will grow to breeding groups to make offspring, which in turn increase the population and restore the resources (Jeong \& Jeon, 2008). The restoration of fish resources can only be achieved by improving the physical environment of the habitat, recovering the damaged habitat, and restoring the fish population together. For the conservation of endangered species, it is very important to clarify the reproductive characteristics and to produce artificial seedlings. A few studies have been re-

\footnotetext{
Manuscript received January 26, 2018, Received in revised form March 3, 2018, Accepted March 14, 2018

${ }^{\dagger}$ Corresponding Author : Won-Kyo LEE, Dept. of Aqualife Science, Chonnam National University, Yeosu 59626, Korea. Tel: +82-61-659-7161, Fax: +82-61-659-7160, E-mail: wklee196@jnu.ac.kr

This is an Open Access article distributed under the terms of the Creative Commons Attribution Non-Commercial License (http:// creative-commons.org/licenses/by-nc/3.0) which permits unrestricted non-commercial use, distribution, and reproduction in any medium, provided the original work is properly cited.
} 
ported on slender catfish: Comparison of carotenoid pigments in catfish, Parasilurus asotus and slender catfish, Parasilurus microdorsalis in the family siluridae (Baek et al., 2004), Comparison of carotenoid pigments in catfish, Parasilurus asotus and slender catfish, Parasilurus microdorsalis in the family siluridae (Park et al., 2004), Comparison of ultrastructure of spermatozoa of two catfish, Silurus asotus and S. microdorsalis (Kwon \& Kim, 2004), and osteological study of Silurus microdorsarlis (Lee \& Kim, 1987).

In present study, we aimed to explore the reproductive cycle of Silurus microdorsarlis, a Korean endemic species, to lay grounds for species conservation, genetic resource procurement and the restoration of mountainous river ecosystem.

\section{MATERIALS AND METHODS}

\section{Sampling}

A total of 10 female and male Silurus microdorsalis were collected monthly from Sueocheon tributary near Jinsangmyun, Gwangyangsi, Jeollanamdo ( $35^{\circ} 01^{\prime} 21^{\prime} \mathrm{N}, 127^{\circ}$ 43'12”E) during January to December 2013 using weir traps and skimming nets. Collected samples were delivered to the laboratory facility alive, to dissected carefully.

\section{Environment investigation}

Water temperature was measured using digital thermometer during sampling. For day length, we recorded and converted the day length of every $15^{\text {th }}$ on Suncheon Meteorological Observatory data.

\section{Histological method}

Samples were measured until $0.1 \mathrm{~cm}$ unit scale for length and $0.01 \mathrm{~g}$ unit scale for weight, then the abdomen was dissected to weigh the gonads until $0.001 \mathrm{~g}$ unit scale.

We calculated the gonadosomatic index (GSI) from N' Da \& Deniel method (1993) (gonad weight / body weight $x$ 100) in order to examine the monthly variation in gonadal maturation status.

Excavated gonads were fixed for 24 hours in Bouin's solution (picric acid:formalin:acetic acid $=15: 5: 1$ ), embedded in paraffin and sliced into $5-7 \mu \mathrm{m}$ of serial sections, and then double-stained with hematoxylin and eosin. The female reproductive cycles was defined by follicular development stages in the ovaries, while male reproductive cycle was defined by progress of spermatogenesis stages in the testis.

\section{RESULTS}

1. Monthly variation in water temperature, day length and gonadosomatic index (GSI)

The habitat's water temperature, day length, and the GSI of slender catfish are described in Fig. 1. From December to February, the GSI was $3.90 \pm 1.79,4.68 \pm 1.74$ and $4.70 \pm$ 1.18 for female and $0.56 \pm 0.19,0.59 \pm 0.12$ and $0.68 \pm 0.16$ for male, respectively. The range of water temperature was $5-7^{\circ} \mathrm{C}$ during this period. The water temperature increased from March $\left(12^{\circ} \mathrm{C}\right)$ to August $\left(28^{\circ} \mathrm{C}\right)$, the GSI value began to increase to in March and reach to $11.77 \pm 3.23$ for female and $1.23 \pm 0.33$ for male in May $\left(21.5^{\circ} \mathrm{C}\right)$. After then, the GSI value decreased gradually for both female and male to $8.02 \pm 1.99,6.67 \pm 0.17,5.24 \pm 0.72$, and $0.93 \pm 0.38,0.63 \pm$ $0.10,0.76 \pm 0.15$ in June $\left(24^{\circ} \mathrm{C}\right)$, July $\left(26.5^{\circ} \mathrm{C}\right)$, and August $\left(28^{\circ} \mathrm{C}\right)$, respectively. From September $\left(25^{\circ} \mathrm{C}\right)$ to November $\left(13^{\circ} \mathrm{C}\right)$, water temperature decreased gradually, and the GSI value was $1.39 \pm 0.12,1.36 \pm 0.08,3.12 \pm 0.25$ for female and $0.76 \pm 0.05,0.62 \pm 0.10,0.64 \pm 0.09$ for male, respectively. Regarding day length, it was $9.49 \mathrm{hr}$ in December (the shortest of the year) and gradually lengthened to $10.03 \mathrm{hr}$, $10.56 \mathrm{hr}, 11.56 \mathrm{hr}, 13.03 \mathrm{hr} 13.59 \mathrm{hr}, 14.29 \mathrm{hr}$ in January, February, March, April, May, and June (reaching the longest). Subsequently it decreased to $14.17 \mathrm{hr}$ in July, $13.29 \mathrm{hr}$ in August, $12.25 \mathrm{hr}$ in September, $11.2 \mathrm{hr}$ in October, and $10.2 \mathrm{hr}$ in November. 
A

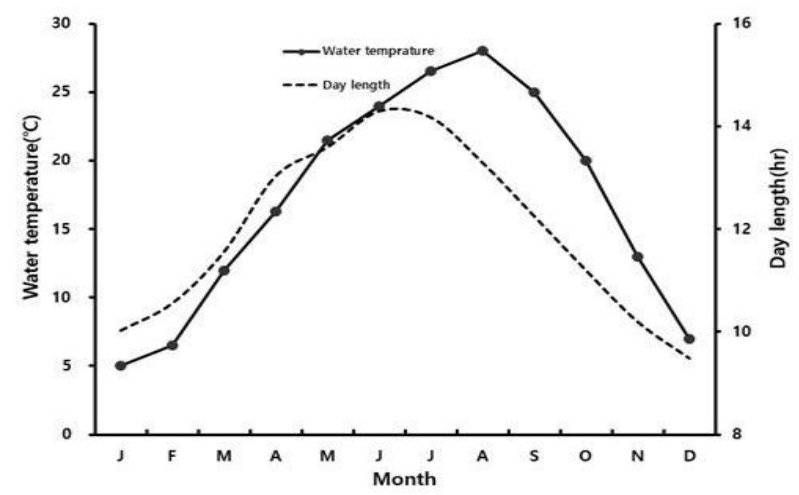

B

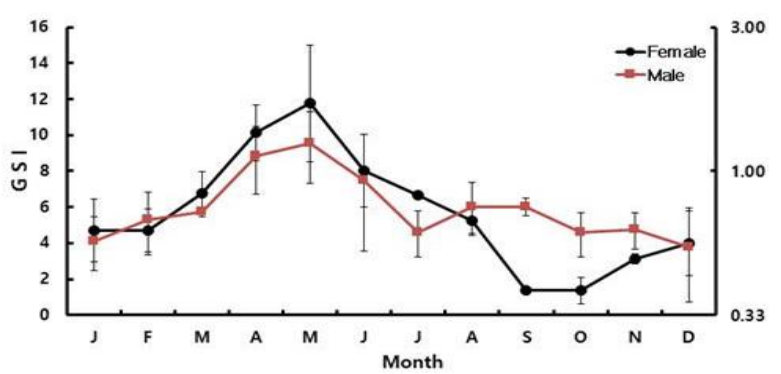

Fig. 1. Monthly variation of water temperature and day length (A), and Gonadosomatic ind ex(GSI) of female and male slender catfish, Siluraris microdorsalis (B). (Circles and bars indicate the mean and standard error).

2. Histological changes of ovaries and the reproductive cycle

Development stages of oocyte and follicles were histologically examined (Fig. 2) and calculated as frequencies. The female reproductive cycle were classified according to Elorduy-Garay \& Ramirez-Luna method (1994) as the growing phase, the mature phase, the ripe and spawning phase, the degenerative phase, and the resting phase (Fig. 4).

The growing stages oocytes (chromatin nucleolus and perinucleolus, and yolk vesicle) were $76.54 \%$ and $23.46 \%$ in December, $71.69 \%$ and $28.31 \%$ in January, $62.85 \%$ and $37.15 \%$ in February.

The maturing stage oocytes (primary yolk globule, secondary yolk globule and tertiary yolk globule) were appeared from March to April. In March, the frequency of primary-tertiary yolk globule stage oocytes was $55.51 \%$.
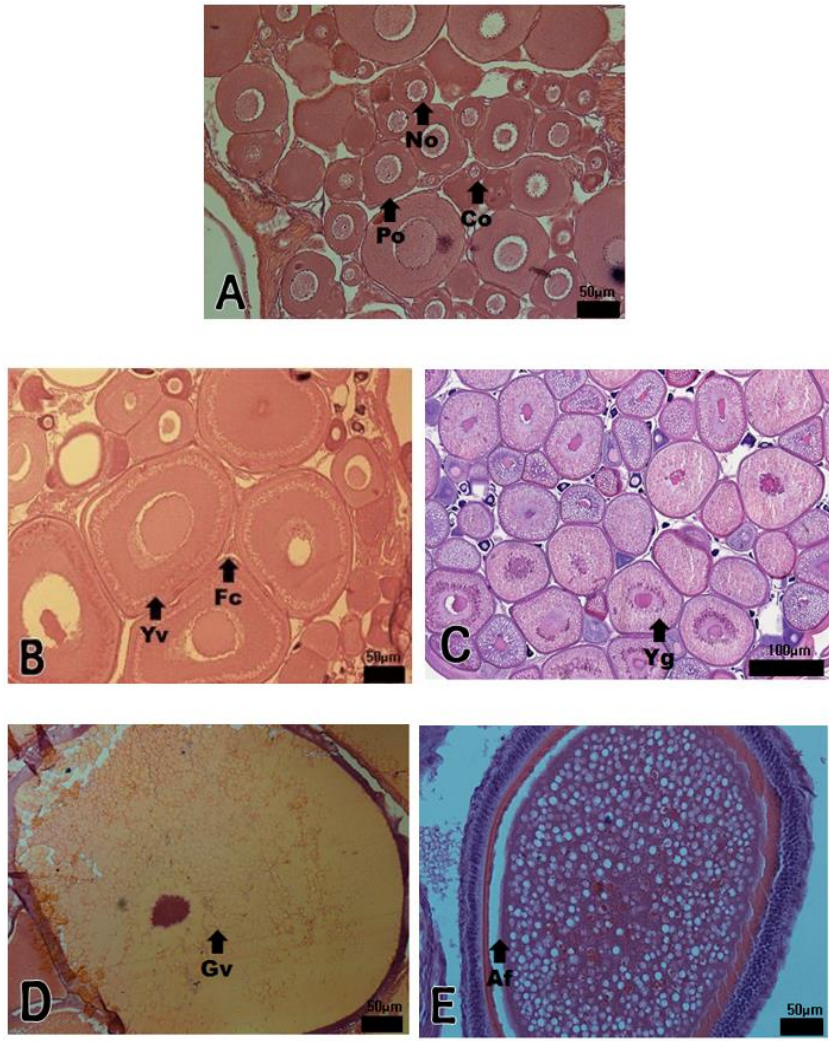

Fig. 2. Ovarian development phase of the Korean slender catfish, Silurus microdorsalis. A: Resting phase. The chromatin-stage oocyte and peri-nucleolus stage oocyte appeared in the ovary. B: Growing phase. Note the yolk vesicles founded in ooplasm. $\mathrm{C}$ : Mature phase. Note yolk globules founded in ooplasm. D: Ripe and spawning phase. The hydrated oocyte appeared. E, Degenerative phase. Remaining full grown oocyte undergoes atresia. AF, atretic follicle; Co, chromatin nucleolus oocyte; Fc, follicle cell; Gv, germinal vesicle; No, nucleolus; Yg, Yolk globule; Yv, Yolk vesicle; Scale bars, 50$100 \mu \mathrm{m}$.

The ripe (hydrated) stage oocytes appeared from May to June, In May, the frequency of ripe stage oocytes and ovulated follicles was $51.58 \%$ and $3.63 \%$, respectively. In June, the frequency of ripe stage oocyte and ovulation follicle was $53.18 \% \%$ and $5.24 \%$, respectively.

From July to August, atretic follicles appeared in the ovary, July-August could be classified as the degenerative phase. The resting stage oocytes (chromatin nucleolus and peri- 

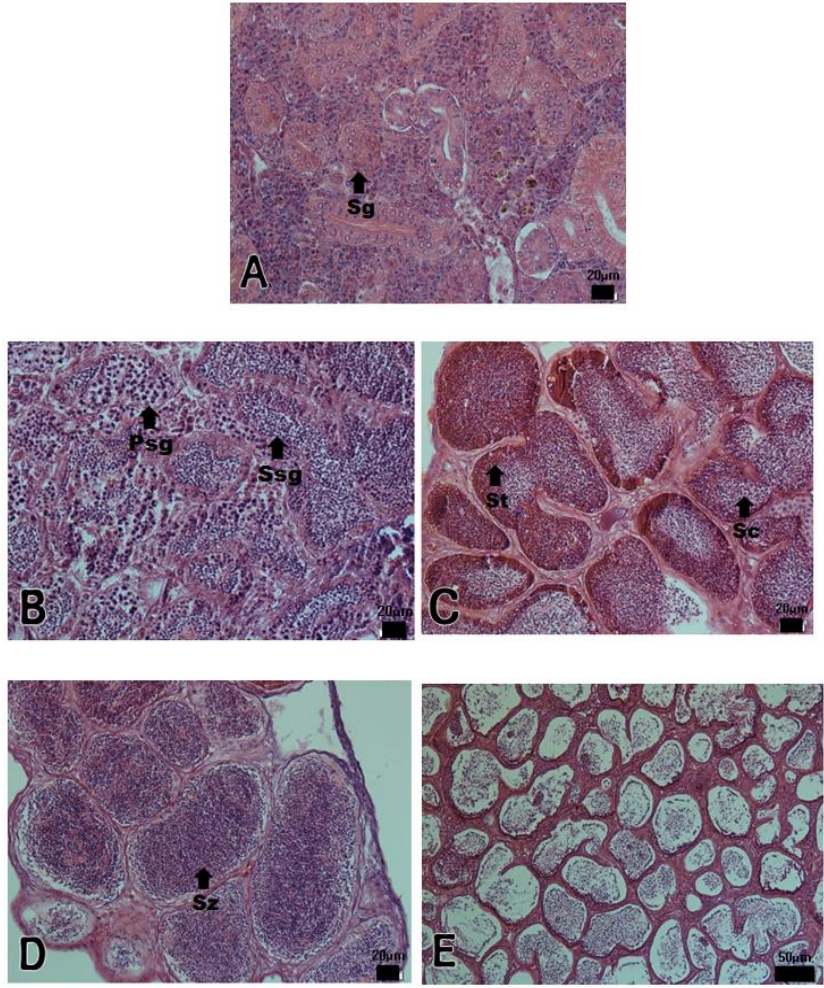

Fig. 3. Testicular development phase of the slender catfish, Silurus microdorsalis. A: Resting phase. The spermatogoina were multiplied in the seminiferous tubule. B: Growing phase. Spermatogonia andsperatocyte filled the seminiferous tubule. C: Maturing phase. Testis become withering spermatid and speratozoa. D: Ripe phase. Note the numerous basophilic spermatozoa. E: Degenerative phase. Seminiferous tubule lumen was almost empty with scanty remaining spermatozoa. g, spermatogonia; St, speratid; Sz, spermatozoa; Ssc, econdary spermatocyte; Psc, Primary spermatocyte; Scale bars: $20-50 \mu \mathrm{m}$

nucleolus, and yolk vesicle) appeared from September to November.

\section{Histological changes of testes and the reproduc-} tive cycle

The progress of spermatogenesis stages were histological examined (Fig. 3), calculated as frequencies. The male reproductive cycle were classified as the growing, the mature, the ripe and releasing, the degenerative, and the resting phase (and Fig. 5).

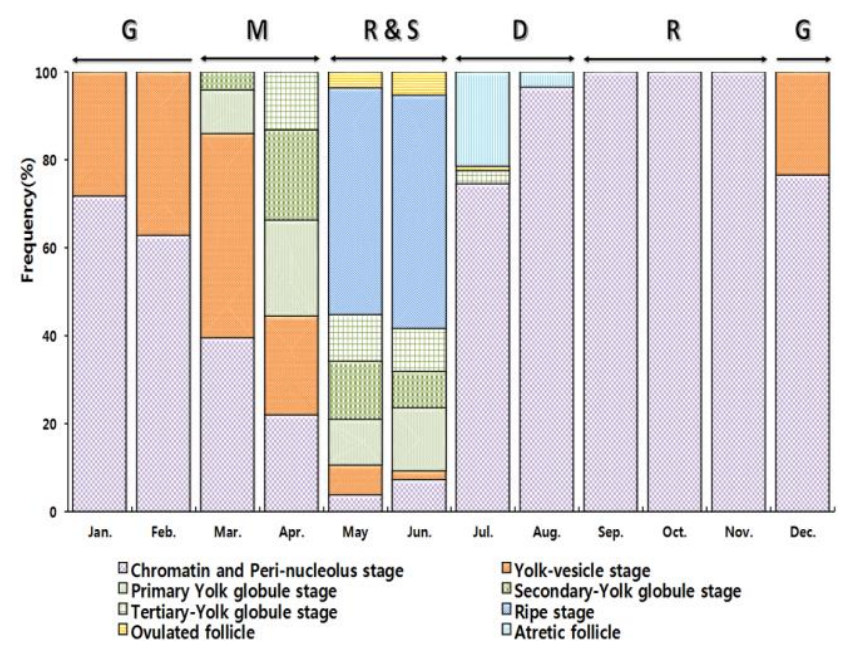

Fig. 4. Monthly change in proportional frequency of ovarian stage of Silurus microdorsalis. D, Degenerative phase; G, Growing phase; M, Mature phase; R\&S, Ripe and Spawning phase; R, Resting phase.

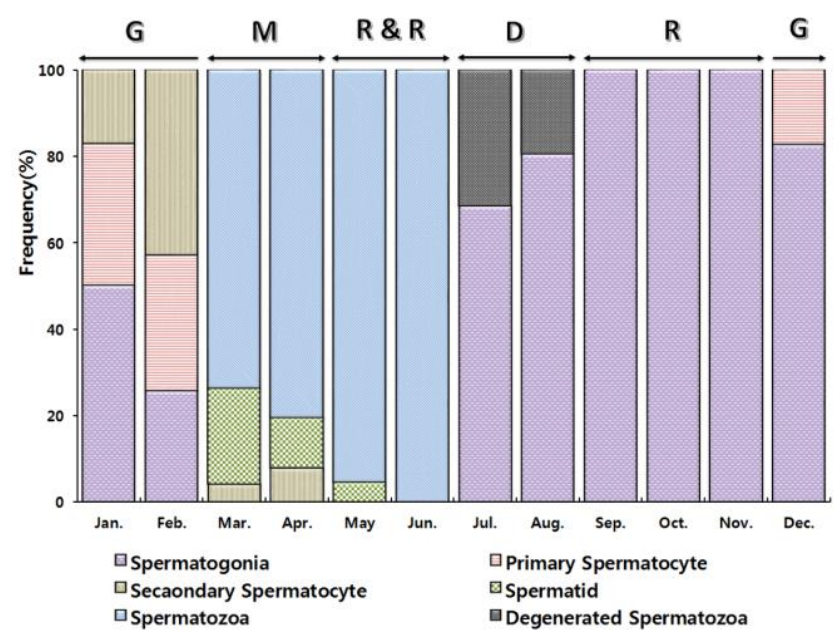

Fig. 5. Monthly change in proportional frequency of testis stage in Silurus microdorsalis. D, Degenerative phase; G, Growing phase; M, Mature phase; R\&R, Ripe phase and Releasing phase; R, Resting phase.

The growing phase (spermatogonia and spermatocyte) of male was from December to February. The frequency of spermatocyte was $17.35 \%$ in December, $49.69 \%$ in January and $74.04 \%$ in February.

The mature phase (spermatocyte, spermatid and spermatozoa) of male was from March to April. The frequency of spermatozoa was $73.65 \%$ in March and $80.32 \%$ in April. 
The ripe and releasing phase (seminiferous tubule of testes with spermatozoa) was from May to June. The degenerative phase was from July to August. A small number of sperm remained in the lumen of seminiferous tubules, after ejaculation. The resting phase (spermatogonia proliferation) was from September to November.

\section{DISCUSSION}

The reproductive cycle of fish is determined by the endocrine system of the hypothalamus-pituitary-gonadal (HPG) axis, which is influenced remarkably by external environmental factors such as water temperature and photoperiod (Vlaming, 1972; Breton et al., 1977; Crim, 1982; Lam, 1983; Razani et al., 1988; Aida, 1991; Shimizu et al., 1994). The fish inhabit the mid-latitudes spawn at the time when their offspring are more likely to survive, and this spawning season repeats every year (Lee et al., 1984). The spawning season, the culmination of the reproductive cycle, is the time when mature eggs and sperm meet to form fertilized eggs that will carry a new generation. Studies on the reproductive cycle of freshwater fish have been conducted to conserve species and production of seeds. There are few comparative studies among major species inhabiting the same water system.

Siluriformes inhabiting major water systems in Korea are the slender catfish Silurus microdorsalis, the South torrent catfish Liobagrus mediadiposalis, the Black bullhead Pseudobagrus koreanus, the bullhead Pseudobagrus fulvidraco and the far eastern Catfish Silurus asotus. Among siluriformes the slender catfish, the South torrent catfish and the Black bullhead are Korean endemic species that live only in Korea (Kim, 1997).

Slender catfish live mountainous stream. South torrent catfish habitats in overlap with slender catfish, but live in a wide area. Black bullhead distribute in the upstream of the main river.

Currently the reproductive cycle of South torrent catfish and Black bullhead are already reported, but not slender catfish.

The reproductive cycles of siluriforms such as South torrent catfish, Black bullhead, bullhead studied to date and has been reported five reproductive stages involving growing phase, mature phase, ripe and spawning phase (releasing for male), degenerative phase, and resting phase (Lim \& Han, 1997; Hwang, 2006; Choi, 2008). The reproductive cycle of slender catfish also showed five stages of growing, mature, ripe and spawning (releasing for male), degenerative, and resting phase.

However the timing and duration of each stages could differ from species to species. South torrent catfish exhibit growing phase in January-February, mature phase in MarchApril, ripe and spawning (releasing for male) phase in May-June, degenerative phase in July-August, and resting phase in September-December (Choi, 2008). Black bullhead also demonstrates growing phase (March-April), mature phase (May), ripe and spawning phase (June-July), degenerative phase (August-September), and resting phase (October-February). On the other hand, bullhead exhibits growing phase (April-early May), mature phase (Mayearly June), ripe and spawning phase (June-August), degenerative phase (September-November), and resting phase (December-March). In Our study, slender catfish represents growing phase (December-February), mature phase (March-April), ripe and spawning phase (May-June), degenerative phase (July-August), and resting phase (September-November). And the reproductive cycle of slender catfish is similar to that of South torrent catfish.

During the mature phase of fish reproductive cycle, yolk accumulation takes place in female oocyte and spermatozoa began to appear in male seminiferous tubules. It is regulated by the hypothalamus-pituitary-gonad axis. Gonadotropin Releasing Hormone $(\mathrm{GnRH})$ release occurs in the hypothalamus by stimulation of environmental factors, and GnRH induces synthesis and secretion of gonadotropin in the pituitary gland. Gonadotropin secretes estradiol 
in follicle of ovary, Estradiol induces synthesis secretion of vitellogenin in hepatocyte, vitellogenin accumulates in oocyte by moving blood flow to ovary. In males, 11-keto testosterone produced in testes plays an important role in spermatogenesis (Nagahama, 1987a; Nagahama, 1994).

However, even if the reproductive cycle of fish is regulated by same physiological mechanism, the environmental impact on sexual maturity in fish differ from species to species. During the mature phase, the water temperature in habitats of South torrent catfish, Black bullhead, bullhead and slender catfish was range of $9-15^{\circ} \mathrm{C}, 13^{\circ} \mathrm{C}, 18-24^{\circ} \mathrm{C}$ and $12-16.3^{\circ} \mathrm{C}$, respectively.

Ripe and spawning phase (releasing for male) in the reproductive cycle of fish is also regulated by the hypothalamic-pituitary-gonad axis. $17 \alpha, 20 \beta$-dihyroxyprogesterone from the follicles stimulate oocyte maturation which is the division of primary oocytes with remained diplotene stage of prophase I to metaphase II. Then matured oocytes proceed the ovulation and spawning. In case of males, 11-keto testosterone and $17 \alpha, 20 \beta$-dihyroxyprogesterone released from testes induced spermiation and releasing of spermatozoa (Young et al., 1982; Nagahama, 1987b). During the ripe and spawning phase, the water temperature in habitats of for South torrent catfish, Black bullhead, bullhead and slender catfish was $21-24^{\circ} \mathrm{C} 23-28.8^{\circ} \mathrm{C}, 24-27^{\circ} \mathrm{C}$ and 21.5 $24^{\circ} \mathrm{C}$ respectively. The water temperature of habitat of ripe and spawning phase also varied according to fish species. However, the temperature range of slender catfish habitat is very similar to that of South torrent catfish habitat.

Fish could be classified into six categories in respect of their spawning phase - spring spawner, spring-summer spawner, summer spawner, spring-autumn spawner, autumn spawner and winter spawner (Aida, 1991). There are three types of Siluridae fish to date: autumn spawner (Pseudobagrus fulvidraco, Liobagrus obesus, Pseudobagrus emarginatus, Leiocassis longirostris), summer spawner (South torrent catfish), and spring-summer spawner (Black bullhead) (Lim \& Han, 1997; Son \& Choo, 1988; Lim, 2009; Hwang,
2006; Choi, 2008). Korean slender catfish spawns from May to June, the water temperature was $21.0{ }^{\circ} \mathrm{C}-24{ }^{\circ} \mathrm{C}$ and the day length was $13.59 \mathrm{hr}$. - $14.17 \mathrm{hr}$. This characteristics coincides with the spring spawner that prefers warmer and longer day length.

Fish could be classified as synchronous, group-synchronous, and asynchronous based on spawning habit. Synchronous development only have one type of developing oocyte within the ovary, and when matured it ovulates once at a specific timing. Group-synchronous development has two distinct group of oocytes in the ovaries during the spawning period. Asynchronous development has various types of oocytes within the ovary, a characteristics of multiple-spawning fish species (Shimizu et al., 1994). The slender catfish showed the synchronous oocyte development in the ovary, which is similar to South torrent catfish and Black bullhead (Choi, 2008; Hwang, 2006).

After spawning, the reproductive cycle of fish proceeds to the next stage, the degenerative phase. The water temperature during degenerative phase was $28-31^{\circ} \mathrm{C}$ (July and August) for South torrent catfish, $27-22^{\circ} \mathrm{C}$ (August and September) for Black bullhead, and $24-8^{\circ} \mathrm{C}$ (September to November) for bullhead. For slender catfish, it was $26.5^{\circ} \mathrm{C}$ in July and $28^{\circ} \mathrm{C}$ in August. The resting phase was September-December for South torrent catfish, October-February for Black bullhead, December-March for bullhead, and September-November for slender catfish. The growing phase was January-February for South torrent catfish, March-April for Black bullhead, April-May for bullhead, and December-February for slender catfish. The slender catfish started its' growing phase earlier than other species.

Considering all these results, the reproductive cycle of slender catfish was very similar to South torrent catfish while quite different from Black bullhead and bullhead. The slender catfish is a Korean endemic living in small tributaries make it very vulnerable to environmental change. Currently the slender catfish has been designated as a protected wild animal in Gyeonggi Province, and it is a fish 
species that has been discharged for resource recovery. In addition to these efforts, we will be able to contribute to conservation of river ecosystems and preservation of endemic species in Korea through the reproductive cycle of the slender catfish in this study.

\section{REFERENCES}

Aida K (1991) Environmental regulation of reproductive rhythms in teleostes. Bull Inst Zool Acad Sin Monogr 16:173-187.

Baek SH, Ha BS, Kim SY, Kweon MJ, Choi OS, Bae TJ, Kang DS (2004) Comparision of carotenoid pigments in catfish, Parasilurus asotus and Slender catfish, Parasilurus microdorsalis in the family Siluridae. Korea J Food Nutr 17:156-162.

Breton B, Billard R, Reinaud P, Escaffre AM (1977) Effects of photoperiod and temperature on plasma gonadotropin and spermatogenesis in the rainbow Trout salmo gairdnerii Richardson. Ann Biol Anim Biochim Biophys 17:331-340.

Choi NH (2008) Reproductive biology of south torrent catfish, Liobagrus mediadiposalis in the Korean Endemic Species. Chonnam National University, PhD thesis, 124.

Crim LW (1982) Environmental modulation of annual and daily rhythms associated with reproduction in teleost fishes. Can J Fish Aquat Sci 39:17-21.

Elorduy-Garay JF, Ramirez-Luna S (1994) Gonadal development and spawning of female ocean whitefish, $\mathrm{Cau}$ lolatilus princeps (Pisces: Branchiostegidae) in the Bay of La Paz, BCS, Mexico. J Fish Biol 44:553-566.

Hwang SW (2006) Studies on the reproductive cycle of a black bullhead, Pseudobagrus koreanus. Chonnam National University, $\mathrm{PhM}$ thesis, 10-30.

Jeon SR (1984) Studies on the key and distribution of bagrid and silurid fishes (Siluriniformes) from Korea. Sangmyung University, Thesis, 14:83-115.
Jeong DS, Jeon CY (2008) Genetic variability and population structure of olive flounder Parlichthys olivaceus from stocked area using microsatellite DNA markers. Korea J Ichthyol 20:156-162.

Kim IS (1997) Illustrated encyclopedia of fauna and flora of Korea. Freshwater fishes, Ministry of Education, Seoul 37:629.

Kwon AS, Kim KH (2004) A comparison of ultrastructures of spermatozoa of two catfish, Silurus asotus and $S$. microdorsalis (Teleostei: Siluridae). Korea J Ichthyol $16: 128-134$

Lam TJ (1983) 2 Environmental influences on gonadal activity in fish. Fish Physiology 9:65-116.

Lee CY, Kim IS (1987) A osteological study of Silurus microdorsarlis (Mori), (Siluridae, Siluriformes). Korea J Limnol 20:129-137.

Lee TY, Hanyu I, Furukawa K (1984) Effect of photoperiod and temperature on the gonadal activity in small filefish, Rudarius ercodes. Fish Aquat Sci 17:523-528.

Lim SK, Han CH (1997) Annual reproductive cycle of the banded catfish, Pseudobagrus fulvidarco (Richardson). Korea J Aquat Sci 30:823-833.

Lim SK (2009) A study on the aquaculture of long snout bullhead and bagrid catfish. National Fisheries Research \& Development Institute, pp. 46-57.

Mori T (1936) Descriptions of one new genus and three new species of Siluroidea from chosen. Zool Mag (Japan), 48:671-675.

N' Da K, Déniel C (1993) Sexual cycle and seasonal changes in the ovary of the red mullet, Mullus surmuletes, from the southern coast of Brittany. J Fish Biol 43:229-244.

Nagahama Y (1987a) Gonadotropin action on gametogenesis and steroidogenesis on teleost gonad. Zool Sci 4:209-222.

Nagahama Y (1987b) 17a,20ß-Dihydroxy-4-pregnen-3one: A teleost maturation-inducing hormone. Dev Growth Differ 29:1-12. 
Nagahama Y (1994) Endocrine regulation of gametogenesis in fish. Int J Dev Biol 38:217-229.

Park IS, Im JH, Hur JW (2004) Morphometric characteristics of catfish (Siluridae) In Korea. Korea J Ichthyol $16: 233-228$

Park IS, Kim CH (2005) Characteristics of the histological structure of the mandibular barbels of two species of catfish (Siluridae) from Korea. Korean J Ichthyol 17: $36-42$.

Razani H, Hanyu I, Aida K (1988) Environmental influences on activity activity and related hormones in yearling goldfish. Nippon Suisan Gakkaishi 54:1513-1520.

Shimizu A, Aida K, Hanyu I (1994) Effects of photoperiod and temperature on gonadal activity and plasma steroid levels in an autumn-spawning bitterling, Acheilognathus rhombea, during different phase of its' annual reproductive cycle. Gen Comp Endocrinol 93:137-150.

Son YK, Choo IY (1988) Ecological studies of catfish, genus Liobagrus from Korea. Korea J Limnol 21:243251.

Vlaming VL (1972) Environmental control of teleost reproductive cycles: A brief review. J Fish Biol 4:131140 .

Young G, Kagawa K, Nagahama Y (1982) Section of aromatizable $\Delta 4$ androgens by thecal layers during estradiol-17 $\beta$ production by ovarian eollicles of amago salmon (Oncorhynchus rhodurus) in vitro. Biomed Res $3: 659-667$ 